一第1日9月11日(火) 14:00 15:00

10207

\title{
L007＼cjkstart幼児期の知識獲得における帰納推論一因果関係に基づく属性推論 の発達一
}

\author{
講演者：石田 有理（お茶の水女子大学／十文字学園女子大学） \\ 司会者：内田 伸子 (お茶の水女子大学)
}

本研究では, 幼児期における帰納推論の発達について検討した。幼児期は, 様々な領域において, 豊富 に知識を獲得していく時期であり, 子どもは既有知識と新しい情報を関連づけながら知識を構造化して いくといえる。そこで, 本研究では, 幼児の属性の一般化に扔ける帰納推論を検討し, 既有知識の利用 可能性が幼児の帰納推論に影響を与えることを示した。また, 幼児は属性同士を因果的に関連づけて推 論を行っていることが示され，幼児期の帰納推論における属性間の因果関係の役割を示唆した。 